\title{
Infant feeding: the interfaces between interaction design and cognitive ergonomics in user-centered design
}

\author{
Flavia Lima ${ }^{\mathrm{a},{ }^{*},}$ Lilian Kely Araújo ${ }^{\mathrm{b}}$ \\ ${ }^{a}$ Master in Architecture and Urbanism (UFMG), Post-Graduate in Ergonomics (UFMG), Environment Designer \\ (UEMG), Rua Juca Cândido 931-Bairro Jardim Cambuí, Sete Lagoas-MG/BRASIL/ CEP:35700-060. \\ ${ }^{\mathrm{b}}$ Post-Graduate in Interaction Design (PUC-Minas), Product Designer (UEMG).
}

\begin{abstract}
This text presents a discussion on the process of developing interactive products focused on infant behavior, which result was an interactive game for encouraging infant feeding. For that, it describes the use of cognitive psychology concepts added to interaction design methodology. Through this project, this article sustains how the cooperative use of these concepts provides adherent solutions to users' needs, whichever they are. Besides that, it verifies the closeness of those methodologies to boundary areas of knowledge, such as design focused on user and ergonomics.
\end{abstract}

Key words: Design, Ergonomics, Cognition, Children, Feeding

\section{Introduction}

The object of study of this article consists in inspecting the importance of interdisciplinarity between interaction design and other areas of knowledge such as psychology and ergonomics on developing an infant interactive product focused on child behavior.

Starting from a free observation of people's behavior in daily situations experience, the project begins without a predefined demand and gains objectives and meanings as long as it deepens on the interactive process of research, analysis and conception. The result of this experience is a collaborative game for children between 2 and 7 years old, named PICNIC. Its main objective is encouraging children to enjoy and recognize the nutritive value of food and feed better. The product concept consists in a playful process of socialization and learning, through an interactive system of a game, in which the good feeding is encouraged as the child relates socially with parents and other children, meanwhile taking care of a virtual friend.
During the process, techniques of design focused on user and infant cognitive psychology fundamentals were crossed for building a cohesive structure of analysis and development which places the PERSON as the center of the creative process.

According to Preece, Rogers \& Sharp (2005) the relevance of the approach centered on user is due to the fact that in the process of creation of an interactive product, it can be tempting to begin with the most practical level of design. However the great risk of this methodological model is the great possibility that the usability goals are easily forgotten. In opposite to this, the approach of design focused on user proposes a process of the bottom up kind, in which the demand arises from real and daily user needs.

Com isso o que queremos dizer é que é necessário conceitualizar o que e se deseja criar e pensar em porque fazer isso. É preciso então refletir sobre como o design poderá fornecer suporte às pessoas em suas atividades diárias e no trabalho. (PREECE, ROGERS \& SHARP, 2005, p.58)

\footnotetext{
Flavia Lima. e-mail: flavialima_designer@yahoo.com.br
} 
On the proposed project, this conceptualization is made along an interactive process in which the user in intrinsically involved in the idealization of the system, providing requirements for planning what the system should do, how to do it and with which meanings.
Following these concepts, the methodology applied on the development of this product was, therefore, organized on the following way:

Chart 1

Applied methodology

\begin{tabular}{|c|c|c|}
\hline \multirow{6}{*}{ 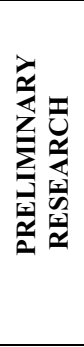 } & \multirow{4}{*}{ Study of behavior } & Observation (filming e notation). \\
\hline & & $\begin{array}{l}\text { Organization of data and inspecting the hypothesis according to action patterns (learned and spontaneous } \\
\text { actions) and relations between individual-object, individual-individual and individual-environment. }\end{array}$ \\
\hline & & $\begin{array}{l}\text { Literature for theoretical analysis of the data according to the psychology of child development and } \\
\text { cognition, and emotional design. }\end{array}$ \\
\hline & & Analysis of collected data according to the theoretical. \\
\hline & \multirow{2}{*}{$\begin{array}{l}\text { Study of the } \\
\text { location of the } \\
\text { problem }\end{array}$} & Survey of hypotheses according to the problems and needs identified. \\
\hline & & Questionnaire for hypotheses testing and closing of the preliminary research phase. \\
\hline \multirow{6}{*}{ 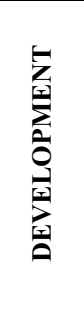 } & \multirow{3}{*}{$\begin{array}{l}\text { System } \\
\text { idealization }\end{array}$} & Theme definition and project objective. \\
\hline & & $\begin{array}{l}\text { Creation of the personas (COOPER, 1999) from the crossing between the observed data profiles and } \\
\text { questionnaire. }\end{array}$ \\
\hline & & Construction of the scenario, map design, system flowchart and use case (PRUITT \& ADLIN, 2006). \\
\hline & \multirow{3}{*}{ Prototyping } & $\begin{array}{l}\text { Low-fidelity prototyping - Interactive process of development from paper prototyping and application of } \\
\text { semi-structured tests with users. }\end{array}$ \\
\hline & & Modeling and Physical Prototyping of the Product. \\
\hline & & Prototyping of the System Interface. \\
\hline
\end{tabular}

\section{Development}

\subsection{Data collection}

On the first stage of the project data was collected, in the form of 7 video registries, about the behavior and the needs of children aged between 2 and 11 years old during the act of feeding, as well as their profile of interaction with objects, space and people (parents and other children).
The natural observation as a data collection technique for identification of requirements is described by Preece, Rogers \& Sharp (2005, p.235) as a tool indicated for understanding the context of user activity. In this project it was used to raise the main issues that make up the universe of performance (scenario) of the project and set up personas that would represent the profiles of users involved in the product utilization. The chart below demonstrates the key observations drawn from this phase:

Chart 2

Observations and features extracted from the relationships established in the real case for the formulation of the problem space.

\begin{tabular}{|l|l|l|l|}
\hline \multicolumn{4}{|c|}{$\begin{array}{l}\text { Analysis summary } \\
\text { - Shootings : } 7 \text { children }\end{array}$} \\
\hline $\begin{array}{c}\text { Children } \\
\text { Age }\end{array}$ & \multicolumn{1}{|c|}{ Place / Situation } & Type of food & \multicolumn{1}{c|}{$\begin{array}{c}\text { Relationship established / } \\
\text { Aspects of problem space }\end{array}$} \\
\hline $\begin{array}{l}2 \text { years } \\
\text { old }\end{array}$ & $\begin{array}{l}\text { At home }- \text { at the table } \\
\text { (with mother) }\end{array}$ & $\begin{array}{l}\text { Yogurt with } \\
\text { ball }\end{array}$ & $\begin{array}{l}\text { The influence of design on the desire }- \text { Of who is the merit of yogurt } \\
\text { appetite, hunger, the situation or the emotional appeal of packaging? }\end{array}$ \\
\hline $\begin{array}{l}3 \text { years } \\
\text { old }\end{array}$ & $\begin{array}{l}\text { At the mall } \text { - at the table } \\
\text { (with mother) }\end{array}$ & $\begin{array}{l}\text { Lunch at } \\
\text { Girafa's }\end{array}$ & $\begin{array}{l}\text { Eating and playful process }- \text { The child does not know the difference } \\
\text { between mealtime and playing time. Attention is dispersed. }\end{array}$ \\
\hline $\begin{array}{l}5 \text { years } \\
\text { old }\end{array}$ & $\begin{array}{l}\text { At home }- \text { at the table } \\
\text { (com um adulto) }\end{array}$ & Macaroni & Creativity and spontaneity - Use of cutlery on an experimental and fun way. \\
\hline
\end{tabular}




\begin{tabular}{|c|c|c|c|}
\hline & & French fries & \\
\hline \multicolumn{4}{|c|}{$\begin{array}{l}\text { Between observation and the need to achieve by } \\
\text { he end of the process a draft of an innovative and } \\
\text { ocused on user product, we could notice the } \\
\text { eculiarity of the projection process by children. We } \\
\text { vere immersed in an environment of individuals in } \\
\text { n intense process of development and } \\
\text { ransformation. Thus, understanding the context does } \\
\text { of merely consider the users as individuals for } \\
\text { tratification in profiles. But understanding, } \\
\text { ynamically, as their relationship is built with the } \\
\text { vorld and, consequently, the product it wanted to }\end{array}$} \\
\hline
\end{tabular}

\subsubsection{Bibliographic survey}

To support the analysis of information from this phase in order to better understand the cognitive and behavioral processes of children, we tried to reference the theories of child development, mainly described by Vygotsky e Piaget.

The mixture of these two lines of study of child behavior is due to their complementary nature. While Piaget focuses on how cognition takes place within the mind rather than the individual's stage of development, Vygotsky discards the biological determinism and suggests the importance of social interactions in the balance between adaptation and evolution, learning and development (SOUZA, 2006).

In this study, observation allowed that aspects of this process of adaptation, learning and development of children were taken to better understand the needs and wishes of the child, and consequently, other individuals with whom it relates during the act of feeding. oup behavior: the child behaves according to the group behavior.

In addition to adaptation, other principles of the development process of the child were used for analysis. Among them are the four stages of the child cognitive development according to Piaget - Scheme, Assimilation, Accommodation and Balance -, the importance of Autonomy, Toy, Rhythm and Rule in the development of the child's relationships with the world and the role of affect in symbolic processes and sensorial-motor behavior and cognition in children.

According to the Theory of Organization Models of Thought, postulated by Moreno, Sartre, Bovet, Leal (1998), from affective and cognitive processes, the subject prepares and organizes syntheses of complex meanings in the understanding of reality and preparing their judgments and actions.

Meanwhile in the design, as reflected Norman (2008), although the analysis of usability and cognitive function is important, the affective analysis is also important because the support of a good design will increasingly be based on user needs, and these in turn are associated with aspects of emotion.

Analyzing the observations in cases of children being fed, the issues of affect and cognition are intertwined to the theory of Emotional Design. When dealing with a new product, or use situations a series of stimuli is trigged from the cognitive processes of perception, from first impressions to more elaborate levels, referring to the social and cultural relations of the child. In Emotional Design (NORMAN, 2008), Norman classifies theses levels of first age, second age and third age of actuation of emotion on Design as: Visceral Design, Behavioral e Reflexive, respectively (see CHART 3).

Chart 3

Chart of observation for refinement of hypothesis

\begin{tabular}{|l|l|l|}
\hline \multicolumn{1}{|c|}{ Visceral Level } & \multicolumn{1}{|c|}{ Behavioral Level } & \multicolumn{1}{c|}{ Reflexive Level } \\
\hline $\begin{array}{l}\text { Present in the processes of perception } \\
\text { and primary sensorial-motor } \\
\text { relationships between children and } \\
\text { the environment and food in the act } \\
\text { of feeding. }\end{array}$ & $\begin{array}{l}\text { Expressed through the use of devices } \\
\text { that support the act of feeding, such as } \\
\text { furniture, cutlery, containers and } \\
\text { packaging. }\end{array}$ & $\begin{array}{l}\text { Embedded in social relations that underlie the act of } \\
\text { feeding, such as the need to belong to a group, the } \\
\text { symbolic representations of the process of } \\
\text { assimilation and child's relationship with the world, } \\
\text { and the relationships that divide parents and children } \\
\text { during feeding. }\end{array}$ \\
\hline
\end{tabular}

\subsubsection{Questionnaire application}

Crossing the collected data and the theoretical literature, we obtained a series of hypothesis for the composition of the problem space and the conceptualization of the project. As a way of validating these hypotheses was applied, then a questionnaire to parents, mothers and caregivers of children aged between 2 and 7 years. 
The main goal of the questionnaire was tested by evaluating the hypothesis that parents tend to have difficulties forming good eating habits in their children in this age group, and that the playful activity and quality of social interactions are important mechanisms to achieve these good habits. In the questionnaire it was evaluated how the type of food generally rejected by the children, the types of activities they like to do as they eat and the strategies used by parents as an incentive to their children appetite.

Reaching a total of only 27 respondents, the questionnaire had taken a weight only exploratory. Still, the mass of data gathered between him and the observation process has amounted to important information for the inauguration of the third step: the development of an interactive project by interbreeding between the data collected and design centered on user techniques described by Preece et al (2005) Cooper (1999) and Pruitt \& Adline (2006). Such techniques include: the construction of scenarios, personas, maps, flow charts and use cases.

\subsection{Personas and goals}

A good Interaction Design is the one that is properly contextualized that serves a real purpose of use (Cooper, 1999). This requires taking into account the purposes and the people who use the system. However, "you can not have purposes without people. The two are inseparable. That's why the two key elements of our design process are goals and personas - purposes and people" (Cooper, 1999, p.149).

Initiating the process of creative design, personas were created, keeping in mind the information collected by observation and questionnaire. With the implementation of project goals, against the goals of personas, the idealization of the project took shape, with definitions of goals, boundaries and guidelines. On one hand the project goals kept the goal in solving the problem raised in the first phase, on the other hand, the goals of personas did consider the solutions that they kept with the focus on user needs.

Below the general listing of goals and their personas:

Chart 4

Personas and Goals

\begin{tabular}{|c|c|c|}
\hline Project Goal & \multicolumn{2}{|c|}{$\begin{array}{l}\text { - Awakening in children appreciation and taste for a healthy and adequate diet; } \\
\text { - Making mealtime a healthy but fun moment; } \\
\text { - Helping in teaching and parental involvement in eating habits of their children. }\end{array}$} \\
\hline \multicolumn{2}{|r|}{ Persona } & Goals \\
\hline \multicolumn{2}{|c|}{$\begin{array}{l}\text { - Carolina, } 5 \text { anos. Caring, serious and smart. Lives in an } \\
\text { orphanage, is malnourished, does not like vegetables. Has a doll } \\
\text { made of Modeling clay after her pet. }\end{array}$} & $\begin{array}{l}\text { - Being accepted by her future adoptive parents; } \\
\text { - Having a normal life like other children who have family; } \\
\text { - Finishing her duties fast so she can play. }\end{array}$ \\
\hline \multicolumn{2}{|c|}{$\begin{array}{l}\text { Max, } 7 \text { anos. Naughty, restless and curious. Lives with his } \\
\text { parents and has a sister and a younger brother. He accompanied } \\
\text { his father on trips, does not like sweet foods in the food. } \\
\text { Exchanges things from his plate with his siblings. }\end{array}$} & $\begin{array}{l}\text { - Playing with his younger brother; } \\
\text { - Not eating what he does not like; } \\
\text { - Get attention from his mother that gives more attention to the } \\
\text { youngest child. }\end{array}$ \\
\hline \multicolumn{2}{|c|}{$\begin{array}{l}\text { Ana Vitória, } 3 \text { anos. Quiet, anxious e dreamer. Lives with her } \\
\text { mother in an apartment. Stay all day with the nanny. Is } \\
\text { overweight. Loves candies. }\end{array}$} & $\begin{array}{l}\text { - Eating whenever she feels like it; } \\
\text { - Staying with her mother; } \\
\text { - Dreaming and having fun with her imaginary friends. }\end{array}$ \\
\hline
\end{tabular}

\subsection{Scenarios}

According to Carroll (2000 apud PREECE, ROGERS \& SHARP, 2005), scenario consists in an informal narrative description that allows exploration and discussion of contexts, behaviors, needs and requirements. Containing a story format, the picture carries the narrative context and other environmental information to help ensure that the proposed project, flow, or use case make sense from the viewpoint of a character. (PRUITT \& Adline, 2006).

The main strengths identified in the application of this methodological step consisted in the opportunity to view the project from the standpoint of the user experience.

In addition, the narrative and contextualized character of this process provided important subjective parameters for detailing the mechanisms of interaction of the future product. 


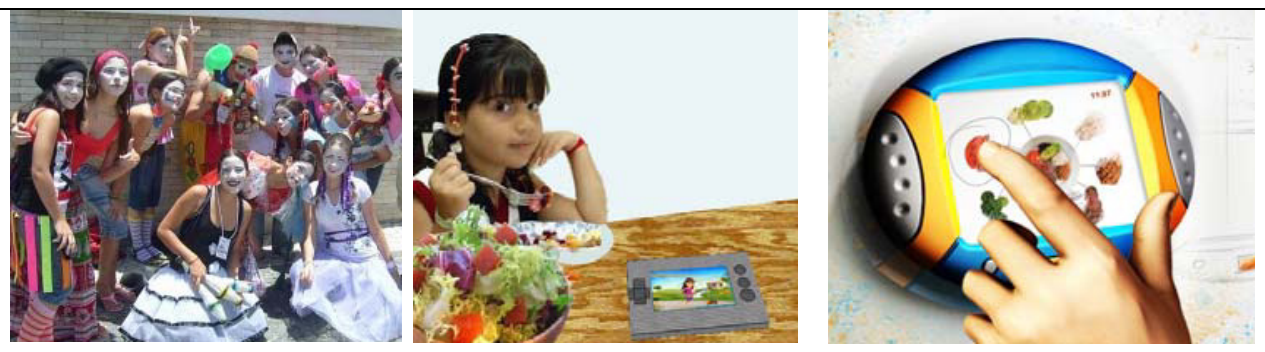

Yesterday around 15:00 the orphanage where Carolina lives was visited by a group of actors that took donations to the orphanage. (...) Through these professionals the orphanage Casa da Criança received donations of 15 computers with com broadband network and 30 portable

Picnic. (...) When a story was shown on TV about the donation of PICNIC Games for the orphanage, Júlia, Ana Vitória's mother, was watching and decided to take Ana Vitória to a different ride on the weekend. (...) Lunchtime is a real party, Carolina show her character for her friends and exchange food, (...) she selects the beet and asks to exchange with her new friend Ana Victoria, who accepts the trade.

\subsection{Design map}

The Desing Map can be used can be used to explore, more deeply, a key scenario, or look at the details of the interaction of a complex resource (PRUITT \& Adline, 2006).

When used in the development process of the Picnic Game the Design Map allowed to transform the system idealizations in more detailed features and modes of operation.

Besides allowing the viewing and detailing of connections and existing failures among the built features, the project objectives according to the designer view and the expected user experience (see Chart 6).

Chart 6

Design Map (cut)

\begin{tabular}{|c|c|c|}
\hline Message receiving & Trade acceptance & Feedback of trade request \\
\hline $\begin{array}{l}\text { Ana Vitória receives the tracie request. } \\
\text { A screen where she selects "yes" or "no", } \\
\text { in this screen is shown the drawing of the } \\
\text { food that will be traded. }\end{array}$ & $\begin{array}{l}\text { Ana Vitoria accepts the trade request } \\
\text { from Carolina e and exchanges the pumpkin } \\
\text { for the beet. }\end{array}$ & $\begin{array}{l}\text { Carolina receives a notification that } \\
\text { her trade request was accepted. }\end{array}$ \\
\hline $\begin{array}{l}\text { When Ana Vitória gets the trade } \\
\text { request the character MOON with happy } \\
\text { face is shown for getting contacted from } \\
\text { friend. }\end{array}$ & $\begin{array}{l}\text { As an acknowledgment for accepting the } \\
\text { request the NICs can get a happiness star. }\end{array}$ & $\begin{array}{l}\text { The feedback with the notification } \\
\text { of exchange is an audio signal that } \\
\text { notifies "Well done! You exchange was } \\
\text { accepted I". }\end{array}$ \\
\hline $\begin{array}{l}\text { How would NIC react if the reques } \\
\text { were denied? }\end{array}$ & & $\begin{array}{l}\text { Se a Ana Vitória arrependesse de } \\
\text { trocar a abobora pela beterraba? Como } \\
\text { ela faria para desfazer a ação? }\end{array}$ \\
\hline Features & Desinger idealizations & $\begin{array}{l}\text { Concerns according to the } \\
\text { user point of view }\end{array}$ \\
\hline
\end{tabular}

\subsection{Flowchart}

The flowchart can explore different possibilities to experience the system. It can be used to discover stories, or identify points of failure that may arise with the complexity of the flow. It can also be used to analyze the implications of a history and implementation planning for the project (PRUITT \& Adline, 2006. 
In the project in question the flowchart was responsible for explaining the logic of the system, allowing to identify more clearly the main steps that build the base of the system and the derived steps, which contextualize and give color to the process of interaction.

Chart 7

Flowchart Details (cut)

Main Steps

\subsection{Case of use}

The Case of Use is another way to detail the interaction. If the Map Design focuses on the human side, cases of use allow to see in more details how the computer system works (PRUITT \& Adline, 2006).

Through the Case of Use it was possible to test conceptually the product in a situation of use, literally simulating the practical use of the planned system. At this level, the technical, physical and subjective aspects of the project had grown much more palpable. As well as closer became the idealization and modeling of the proposed system.

\subsection{Modeling, prototyping e iteraction}

Unlike many methodological approaches to design in which the prototype takes a final position of validating the design solutions, in this work, the prototype is part of an iterative process of development. It takes part in the stages of conceptualization and modeling system. This was made possible by the technique of Paper Prototype, which throughout the creation process are made of low-fidelity prototypes on paper and rapid tests used to generate direct feedback to the solutions generated.

Picture 1

Modeling e Prototyping

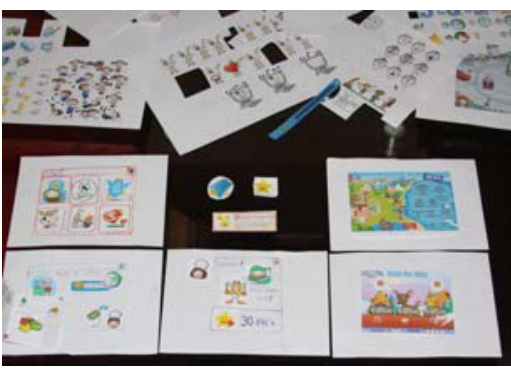

a. Paper Prototype

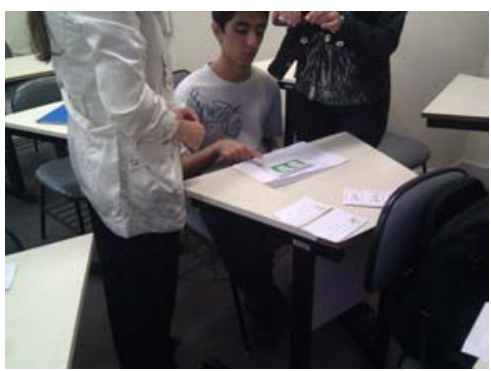

b. Quick tests

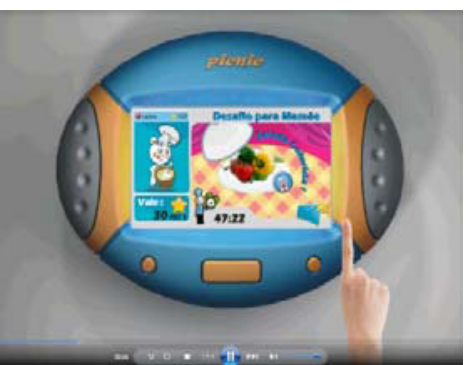

c. 3D Simulation
In this methodology, as the project progresses, the prototypes become more refined and doubts and mistakes are being monitored and resolved by the application of rapid testing and iteration, thus reducing risks, unnecessary work and costs.

\footnotetext{
${ }^{1}$ Checks available food from online friends, messages and number of points for trading.

${ }^{2}$ Shows score of virtual pet; proposes games.

${ }^{3}$ At lunchtime, the game turns on by itself

${ }^{4}$ Sends message to friend
} 
At the end 3D modeling and simulation of game function close the project configuration and allows a better view as how the final product will be.

\section{Discussion about the test}

The Interaction Design methodology applied in this study allowed us to experience a developmentdriven user experience, crossing techniques in order to open the area for new designer's domain knowledge and risk new solutions.

The mixture of these areas of expertise allowed at the end of the project, reread the whole process and assess that, despite not having applied directly to the methodology of ergonomics during the procedure done, it is possible to see similarities in the processes of design focused on user, cognitive psychology, emotional design, interaction design and methodology used by ergonomics. The convergence among these areas could be seen on the following points:

- Ergonomics e Interaction Design are focused on human beings:

The goal of ergonomics is to contribute to the design by objects, services, living and working environments. It is a tool that seeks design by respecting the limits of man and their capacities, always aiming to improve the system with which humans interact. At this point the Design focused on user converges to the methodology of ergonomic action, as long as they are disciplines and areas of knowledge oriented to the demand / problem. According to Bagnara (2000):

The relations between design and ergonomics has always been difficult, if not conflicting. Designer say ergonomists have an inspective/normative mentality. [...] Besides that, for designers, ergonomists seem to prefer what is "safe" and stable rather than innovation and creativity. [...]However, in fact, the relationship between ergonomics and design have also produced, and now more than ever, results. [...] Both professions are becoming aware of how alike they are. [...] Ergonomics (I believe the speech is also substantially applicable to design; I say of ergonomics because I know it more) derives its knowledge from disciplines such diverse as physiology and sociology, organizations theory and biomechanics, a psychology and the systems theory [...] Not only ergonomics, but also design, is focused on the problem: it is because of the problem to be solved that come the necessary academic knowledge. (BAGNARA, 2000)

- Observation and tests with users: common techniques for Ergonomics and Interaction Design:

In the first stage of the project, it is observed the use of important methodological tools within the ergonomic analysis such as: on-site observation, filming and notes as well as a questionnaire. These are the starting point for the assessment of demand and structure of the study hypotheses. Likewise, understanding human behavior is crucial for the development of a "good" ergonomic analysis. Bagnara, (2000) states that for ergonomics, "the problem is always on the relationship between the man and his activity, the man and his environment of life" (BAGNARA, 2000). That is, the problem only exists when contextualized (GUERIN et al, 2001; WISNER, 1987; LIMA, 2000).

The third phase of the trial exhibit also shows similarities between the methodologies to establish parameters for the low-fidelity prototyping, performed precisely with the intention of testing with users focus. To Bagnara (2000), "design centered on user is not only a projection methodology, but above all a profession of 'scientific humility', because it expresses the consciousness of human subjectivity, diversity among men, and the diversity of self-in contexts and different activities that can not be fully described with the traditional scientific knowledge". Thus, the validation parameters of solutions designed (the designer, the ergonomist, the engineer) will always be the actual person who will live with the solution adopted.

5 Il rapporto fra design ed ergonomia è sempre stato difficile, per non dire conflittuale. I designer attribuiscono agli ergonomi una mentalità ispettivo/normativa. [...] Inoltre, per il designer, gli ergonomi sembrano preferire ciò che è sedimentato rispetto all'innovazione e alla creatività. [...] Eppure, nei fatti, il rapporto fra ergonomia e design si è sempre tenacemente riproposto, e ha anche dato, e dà ora più che mai, frutti. [...]Le due professioni stanno prendendo consapevolezza di quanto siano simili. [...] L'ergonomia (credo che il discorso sia sostanzialmente applicabile anche al design; muovo dall'ergonomia perché la frequento di più) deriva le sue conoscenze da discipline così diverse come la fisiologia e la sociologia, la teoria dell'organizzazione e la biomeccanica, la psicologia e la teoria dei sistemi. [...]L'ergonomia, ma anche il design, è orientata al problema: è in funzione del problema da affrontare che vengono attivate le conoscenze disciplinari necessarie. (BAGNARA, 2000). 
- Ergonomics and Interaction Design include knowledge of psychology to understanding the user:

The incorporation of knowledge of psychology to both areas is due to the fact that the study of issues related to cognition that enables a broader understanding about the actual behavior and decisions taken during the action.

[...] is evident that knowledge on the health of the worker are of little use to confront the issues posed by today's designers about the product from the customer. [...] Ergonomics learns it has a knowledge deficit, partly coincident to that has the design. In 80 years develops an area of ergonomics, cognitive ergonomics, which has the responsibility to cover this shortage. (BAGNARA, 2000) ${ }^{6}$.

The cognitive ergonomics is a tool that seeks to understand how human beings perceive the stimuli around them and acts in the middle, with the aim of simplifying the mechanisms to facilitate the task. According to Chapanis (1996), human beings, given a stimulus, process the received information and produces a result in the form of an answer.

In this approach, according to Bagnara (2000), "therefore, becomes crucial to the ergonomics knowledge derived from the study of cognitive, communicative and relational".

\section{Final considerations}

In this report on the applied design methodology it was possible to understand the nature of the proximity or even the equalities that exist in methodological processes of interaction design and ergonomics, as Bagnara (2000) shows in his text on Ergonomics and Design. And thus conclude that both are areas that act as a problem is presented to them, a demand. However, it is the ability to search on user behavior and its relations with the object and the means to understand their real needs, desires and mental models that ensure the achievement of

\footnotetext{
6 [...] dei problemi riguarda la sicurezza e la salvaguardia della salute nel "lavoro travaglio" è evidente che le relative conoscenze saranno di ben scarsa utilità per affrontare le questioni poste dal designer sul cliente del prodotto servizio. [...] L'ergonomia scopre di avere un deficit di conoscenza, in parte coincidente a quello che avverte il design. E negli anni ottanta si sviluppa un'area dell'ergonomia, l'ergonomia cognitiva, che si assume il compito di coprire questa carenza. (BAGNARA, 2000).
}

optimal solutions to use, which, in turn, is one of the principles of ergonomics.

\section{Acknowledgements}

We would like to thank the co-authors of the project: Juliana Pappa e Rafael Catalan.

\section{References}

[1] ARANTES, V. A. Afetividade e Cognição: rompendo a dicotomia na educação. In: VIDETUR, n. 23. Porto/Portugal, Mandruvá, 2003, Disponível

em: $<$ http://www.hottopos.com/videtur23/valeria.htm) $>$ Acesso em 07 abr. 2011.

[2] BAGNARA, S.. Ergonomia e design. Politecnico di Milano, 2000.

[3] CHAPANIS, A.. Human Factors in Engineering Design. New York, NY: Wiley, 1996)

[4] COOPER, A.. The inmates are running the asylum. Sams USA, 1999.

[5] DAVENPORT, T. H.; BECK, J. C.. The attention economy: understanting the new currency of business. Cambridge: Harvard Business School, 2002.

[6] GUÉRIN, F; LAVILLE, A; DANIELlOU, F.; DURAFFOURG, J.; KERGUELEN, A.. Compreender o Trabalho para Transformá-lo: A Prática da Ergonomia. São Paulo, Edgard Blücher, 2001.

[7] LIMA, F. P. A. . Ergonomia e projeto organizacional: a perspectiva do trabalho. Produção (São Paulo), Rio de Janeiro, v. especial, p. 71-98, 2000.

[8] NORMAN, D. A.. Design Emocional: por que adoramos (ou detestamos) os objetos do dia-a-dia. Rio de Janeiro: Rocco, 2008.

[9] NORMAN, D.; DRAPER, S. W. (Eds). User centered system design: new perspectives on human-computer interaction. Hillsdale, NJ: Lawrence Erlbaum Associates, 1986.

[10]PREECE, J.; ROGERS, I. \& SHARP, H. Design de Interação: além da interação humano-computador. Porto Alegre: Bookman, 2005.

[11]PRUITT, J \& ADLIN, T. The persona lifecycle: keeping people in mind throughout product design. EUA: Morgan Kaufmann, 2006.

[12]ROVER, Aires; CARVALHO, Marisa. A Integração Emoção e Cognição no Contexto da Cultura Projetual. Infojur. UFCS, 2009.

[13] VYGOTSKY, L. S. A Formação Social da Mente. São Paulo, Martins Fontes, 1991.

[14] WISNER, A.. Por Dentro do Trabalho - Ergonomia: método e técnica. FTD/Oboré, 1987. 